\title{
Effect of the addition of synthetic fuel on the selected physico-chemical properties of the fuel for the diesel engines
}

\begin{abstract}
Plastics present a major threat to today's society and environment. Though mankind has awoken to this threat and responded with developments in creating degradable bio plastics, there is still no conclusive effort done to repair the damage already caused. In this regard, the catalytic depolymerization studied here presents an efficient, clean and very effective means of removing the debris that we have left behind over the last several decades. By converting plastics to fuel, we solve two issues, one of the large plastic seas, and the other of the fuel shortage. This dual benefit, though will exist only as long as the waste plastics last, but will surely provide a strong platform for us to build on a sustainable, clean and green future. The paper presents results of density, viscosity, cetane number, ignition temperature of 100\% synthetic fuel and this fuel's mixture with the diesel oil. The quality of the fuel-air mixture formation is best characterized by the SMD parameter - Sauter's average diameter of spray drops, and its value in analytical studies depends on the physical parameters of the fuel (density, viscosity, surface tension). The results of laboratory tests will be developed in terms of the use of the measured parameters of a synthetic fuel mixture to calculate SMD values and to correct analytical equations taking into account the actual SMD values measured by laser diffraction laboratory tests.
\end{abstract}

Key words: alternative fuels, polymer materials, synthetic fuel, diesel engines

\section{Introduction}

Over the past 150 years, plastics have enabled innovation and contributed to the development of society and the growth of its prosperity. Thanks to plastics, the society can meet challenges of the 21 st century. Only 4 to $6 \%$ of the world oil production is consumed for its production. Plastics are the material commonly used for the production of a wide variety of products that are applicable in practically all areas of life. As a consequence, the share of these wastes in the municipal waste stream is increasing, which is a serious environmental problem. Due to the value of the raw material, all plastics waste should be recovered - either by recycling or by energy recovery. One way to utilize and use them is to convert them into liquid synthetic fuel.

\section{Alternative fuels}

Selected physicochemical properties of the fuel have been determined, which have a decisive influence on the correct operation of the internal combustion engine, its performance and the cleanliness of the exhaust gases emitted into the environment. The primary raw material for the production of engine fuels is crude oil, whose consumption has steadily increased over the recent years. Increasing demand for liquid fuels with scarce resources, rising oil prices and tougher environmental regulations has led to the need for new alternative energy sources.

Alternative fuels are divided into gaseous and liquid fuels. Synthetic fuel is classified as liquid fuel and obtained by chemical synthesis [1].

The fuel used to supply the internal combustion engines should be characterized by specific parameters that determine the proper operation of the engine. Values of these parameters are given in the relevant normative documents: specifications, technical conditions, industry standards for compliance with the given state standards, common standards for associated countries (e.g. EU), international organizations' directives (e.g. World Fuel Charter).

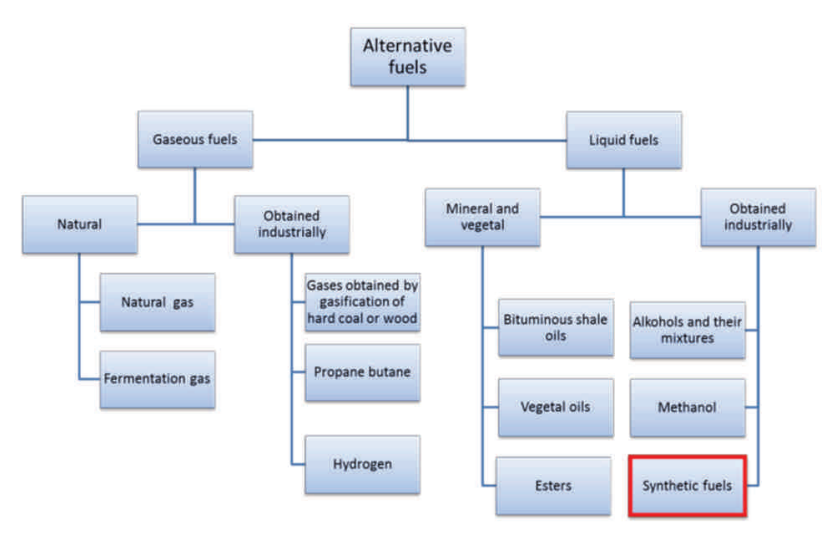

Fig. 1. Division of alternative fuels [3]

\section{Polymer materials}

Thanks to polymer materials we have the opportunity to create new products. They allow greater technological progress than any other material. Plastics thanks to the economy of raw materials and materials are one of the most efficient products. Only small part of the world's crude oil resources is used for their production.

More than 50 years ago the potential of these materials was discovered, but their era is only now beginning. Thanks to their properties, plastics are used in packaging, construction, automotive industry, aerospace industry, agriculture, sport, medicine. In 2015, the demand for plastics in Europe amounted to 49 million tons [6].

However, when plastic products cease to fulfill their utility functions and their life cycle ends, they must be appropriately recovered.

Plastic waste is dominated by polyolefins, i.e. polymers containing carbon and hydrogen, which are extracted directly from crude oil. Polyolefins are durable, rigid and abrasion-resistant. In addition, they have good dielectric properties, are resistant to water, have high gas permeability and low for water vapor. On the other hand, they are not 
resistant to strongly oxidizing substances and atmospheric conditions cause their aging. Polymers include: polyethylene (PE), polypropylene (PP), polystyrene (PS), and acrylonitrile-butadiene-styrene (ABS). The first one is odorless and physiologically indifferent, but easy to burn. We can distinguish high density polyethylene (PEHD) and low density (PELD). PEHD is more mechanically resistant, has higher melting points and hardness and degree of crystallinity. Polypropylene allows to obtain transparent products with low absorbency and water permeability, and also impervious to gases [2].

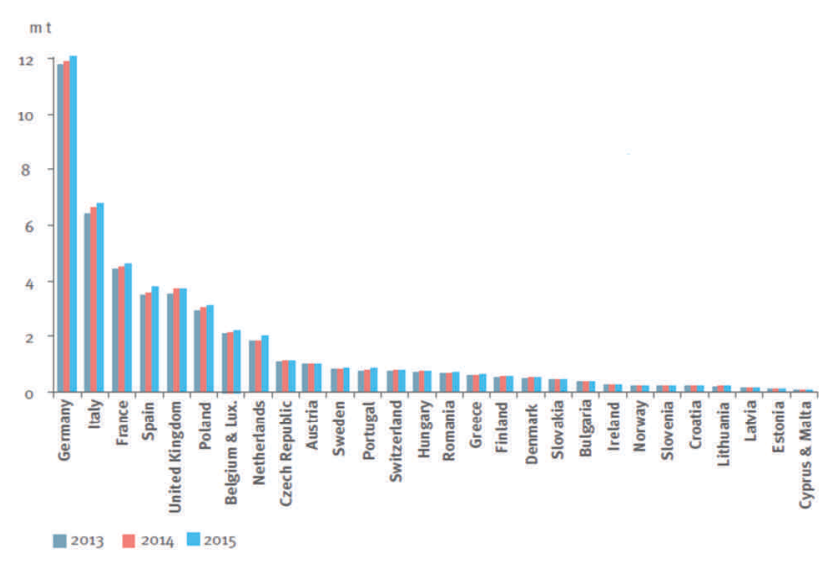

Fig. 2. Demand for Polymeric Plastics in Europe 2013-2015 [6]

Plastics account for about $10 \%$ by weight and $40 \%$ by volume of the household waste. The main source of plastic waste is packaging, which accounts for $55 \%$ of post consumer waste from plastics.

Waste from polymeric plastics can be utilized by:

- mechanical recycling,

- raw material recycling,

- energy recovery,

- processing into liquid synthetic fuel.

According to the National Alternative Fuel Infrastructure Development Plan, synthetic fuels are fuels obtained by chemical synthesis using various methods and raw materials. Synthetic fuels can be divided by the raw material used: 1. Fuel obtained from natural gas, so called, Gas to Liquid (GTL), 2. Fuel from coal, so called, Coal to Liquid (CTL), 3. Fuel obtained from biomass, 4. Fuel obtained from plastics (municipal waste) [4].

As a result of chemical processes, synthetic gasoline or synthetic diesel is produced. As a rule, the use of synthetic fuels does not entail the need to build new fueling facilities for vehicles powered by synthetic fuels, these fuels can be used by vehicles running on traditional fuels.

\section{Research}

The tests of physicochemical properties of synthetic fuel and its mixtures have been carried out at the research laboratory of the Research Center for Fuels, Working Fluids and Environmental Protection of the Faculty of Mechanical Maritime Academy.

The tests used:

- DMA 4500/5000 for density determination

- TV 2000 viscometer for determining kinematic viscosity
- Cetane ID 510 for determining a cetane number

- Device for determining the flash point

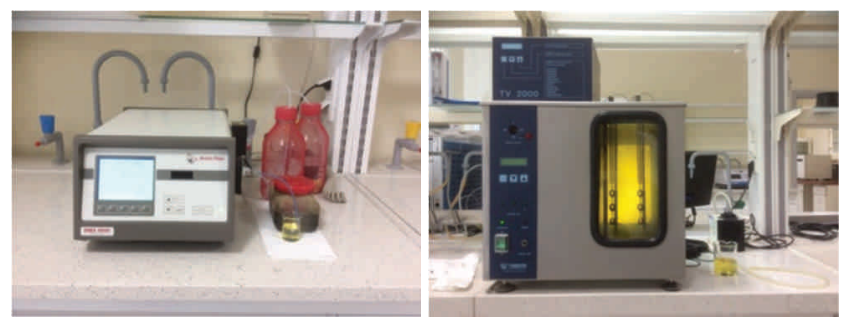

Fig. 3. DMA 4500/5000 for density determination and TV 2000 viscometer for determining kinematic viscosity

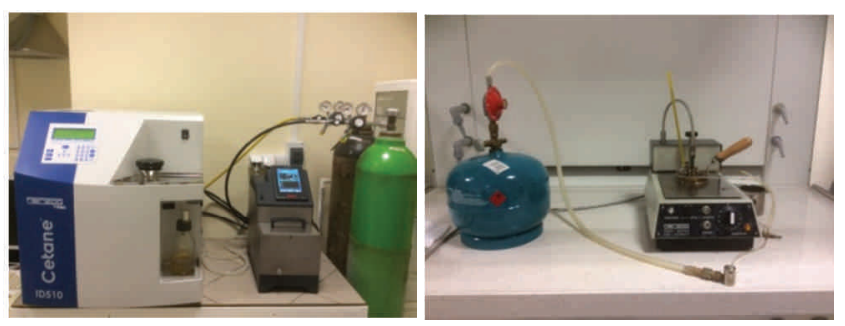

Fig. 4. Cetane ID 510 for determining a cetane number and Device for determining the flash point

Selected physicochemical properties of the fuel have been determined, which have a decisive influence on the proper operation of the internal combustion engine, its performance and the cleanliness of the exhaust gases emitted into the environment.

For studying physico-chemical properties, the liquid fuel was used, which is a mixture of waste made of PE and PP plastics and is produced in an installation that enables to recycle the largest group of plastic waste, i.e. polyethylenes $(\mathrm{PE})$, polypropylenes (PP) and polystyrenes (PS).

The installation processes plastic waste mixed in any proportions of PP to PE or PS, which can come directly from landfills or waste sorting plants.

The plastic waste can be dirty and damp with a different texture and thickness, and may have different colored prints. The recycling process involves catalytic depolymerization. The waste that goes into the plant is converted into a gaseous form which, after cooling and filtration, is the final product of liquid fuel.

One of the main parameters determining the suitability of fuel for the supplying diesel compression engines is the cetane number. The $\mathrm{CN}$ determination is based on a comparison of the ignition properties of the test fuel with the analogous properties of standard fuel mixtures with known cetane numbers.

When using fuel in the engine, the effects of incomplete combustion appear in the form of deposits on the atomizers (injectors) and their amount depends on the fuel contents.

However, the cetane number is not a sufficient criterion for the correct combustion process (complete and total combustion). With both synthetic and fossil fuels, the incomplete combustion can occur, despite the cetane number appropriate for the given ignition engine, and despite the fact that all the parameters of the combustion formation (injection pressure, compression pressure) are correct. 
Additionally, the process of creating a combustible mixture is closely related to the spraying process affected by other physical parameters of the fuel. The density, viscosity, and surface tension of the fuel play a decisive role in the formation of turbulent flow in the spray nozzles, providing proper atomization. The initial phase of supplying fuel to the combustion chamber, consisting of spraying the fuel, is crucial for further processes of preparing the fuel-air mixture, its ignition and combustion. The quality of the fuel-air mixture formation is best characterized by the SMD parameter - Sauter's average diameter of spray drops, and its value in analytical studies depends on the physical parameters of the fuel (density, viscosity, surface tension).

Table 1. Calculation formulas for determining the mean diametre of a drop [5]

\begin{tabular}{|c|l|}
\hline \multicolumn{1}{|c|}{ Equation } & \multicolumn{1}{|c|}{ Author } \\
\hline $\mathrm{SMD}=3330 \mathrm{~d}_{\mathrm{o}}^{0.3} \eta_{\mathrm{L}}^{0,07} \rho_{\mathrm{L}}^{-0.648} \sigma^{-0.15} \mathrm{w}_{\mathrm{L}}^{-0.55} \eta_{\mathrm{A}}^{0.78} \rho_{\mathrm{A}}^{-0.052}$ & Harmon \\
\hline $\mathrm{SMD}=3.98 \cdot 10^{7} \mathrm{~d}_{\mathrm{o}} \mathrm{w}_{\mathrm{F}}^{-1} \sigma^{0.25} \rho_{\mathrm{A}}^{-0.25} \mathrm{~g}^{0.5}$ & $\begin{array}{l}\text { Tanaswa } \\
\text { and Toyo- } \\
\text { da }\end{array}$ \\
\hline $\mathrm{SMD}=6156 v_{\mathrm{L}}^{0.385}\left(\sigma \rho_{\mathrm{L}}\right)^{0.737} \rho_{\mathrm{A}}^{0.06} \Delta \mathrm{p}_{\mathrm{L}}^{-0.54}$ & Elkotb \\
\hline $\mathrm{SMD}=0.38 \mathrm{~d}_{\mathrm{o}} \operatorname{Re}^{0.25} \mathrm{We}_{\mathrm{F}}^{-0.32}\left(\frac{\eta_{\mathrm{F}}}{\eta_{\mathrm{A}}}\right)^{0.37}\left(\frac{\rho_{\mathrm{F}}}{\rho_{\mathrm{A}}}\right)^{-0.47}$ & $\begin{array}{l}\text { Hiroyasu } \\
\text { and Arai }\end{array}$ \\
\hline $\mathrm{SMD}=2362 \mathrm{~d}_{\mathrm{o}}^{0.262} \varrho_{\mathrm{A}}^{0.121} \mathrm{Q}_{\mathrm{F}}^{-0.0665} \Delta \mathrm{p}_{\mathrm{F}}^{-0.0695}$ & $\begin{array}{l}\text { Hiroyasu } \\
\text { and Kadota }\end{array}$ \\
\hline
\end{tabular}

\section{Conclusions}

The results obtained of testing selected physicochemical properties were related to the requirements set by PN-EN 590+A1:2011 standard. Fuels for motor-vehicles Diesel oils - Requirements and test methods [7].

Firstly, pure synthetic polymer fuel and pure diesel were tested and the results compared. Pure synthetic fuel meets the standard only for the cetane number. The parameter that most differs from the norm is the flash point (Table 2). It was therefore reasonable to carry out a fuel mixtures tests with $7 \%$ and $20 \%$ share of synthetic fuel.

In the case of mixtures, we see that the $20 \%$ addition of synthetic fuel slightly changes the density, viscosity and cetane number. However, the flash point is still incompatible with the standard requirements for ON to supply internal combustion engines. By analyzing the results of the $7 \%$ mixture, we find that all the parameters tested are similar to the $\mathrm{ON}$ fuel parameters and meet the requirements set by the standard.
Table 2. Selected physico-chemical parameters of synthetic fuel and diesel oil

\begin{tabular}{|l|c|c|c|c|}
\hline $\begin{array}{l}\text { Test } \\
\text { parameter }\end{array}$ & Unit & $\begin{array}{c}\text { Synthetic } \\
\text { fuel }\end{array}$ & Diesel & $\begin{array}{c}\text { Requirements } \\
\text { for diesel }\end{array}$ \\
\hline density & {$\left[\mathrm{kg} / \mathrm{m}^{3}\right]$} & 795 & 834 & $820-845$ \\
\hline viscosity & {$\left[\mathrm{mm}^{2} / \mathrm{s}\right]$} & 1.76 & 2.768 & $2.00-4.5$ \\
\hline $\begin{array}{l}\text { cetane num- } \\
\text { ber }\end{array}$ & {$[-]$} & 64.4 & 55.8 & $\min 51$ \\
\hline $\begin{array}{l}\text { ignition } \\
\text { temperature }\end{array}$ & {$\left[{ }^{\circ} \mathrm{C}\right]$} & 30 & 65 & $<55$ \\
\hline
\end{tabular}

Table 3. Selected physico-chemical parameters $7 \%$ and $20 \%$ synthetic fuel mixture and diesel oil

\begin{tabular}{|l|c|c|c|c|}
\hline $\begin{array}{l}\text { Test } \\
\text { parameter }\end{array}$ & Unit & $\begin{array}{c}7 \% \text { synthe- } \\
\text { tic fuel }\end{array}$ & $\begin{array}{c}20 \% \\
\text { synthetic } \\
\text { fuel }\end{array}$ & $\begin{array}{c}\text { Require- } \\
\text { ments for } \\
\text { diesel }\end{array}$ \\
\hline density & {$\left[\mathrm{kg} / \mathrm{m}^{3}\right]$} & 831 & 828 & $820-845$ \\
\hline viscosity & {$\left[\mathrm{mm}^{2} / \mathrm{s}\right]$} & 2.672 & 2.456 & $2.00-4.5$ \\
\hline cetane number & {$[-]$} & 56.9 & 57.4 & $\min 51$ \\
\hline $\begin{array}{l}\text { ignition tempera- } \\
\text { ture }\end{array}$ & {$\left[{ }^{\circ} \mathrm{C}\right]$} & 55 & 45 & $<55$ \\
\hline
\end{tabular}

The studies of physicochemical properties conducted will allow to develop a methodology for determining the possibility of using liquid synthetic fuels in compression ignition engines.

In the current standards, the only property of distillation fuels for diesel engines, directly referring to combustion, and reflecting their ignition characteristics, is the cetane number $(\mathrm{CN})$. However, as shown by the analysis of scientific literature on fuels other than petroleum oils, the $\mathrm{CN}$ is not a sufficient parameter to evaluate its usefulness in diesel engines.

As a result of the studies, it was found that both, $100 \%$ synthetic fuel and its $20 \%$ share in diesel fuel did not meet the minimum ignition temperature limit, while the limit value of this parameter is met by the mixture of diesel oil with $7 \%$ synthetic fuel. Currently, the laboratory tests are being developed with regard to the use of measured viscosity, density and surface tension values for a mixture of synthetic fuels (up to $7 \%$ and petroleum oils), SMD calculation and analytical equations corrections taking into account the actual SMD values measured by laser diffraction method during the laboratory tests. The further direction of research is related to the definition of the operating and environmental parameters of a diesel engine fuelled with diesel oil with $7 \%$ synthetic fuel.

\section{Bibliography}

[1] BALAWENDER, K., JAKUBOWSKI, M., KUSZEWSKI, H. Parametry fizykochemiczne paliwa syntetycznego przeznaczonego do zasilania silników o ZS. Вісник Національного транспортного університету. 2014, 30(1).

[2] CICHY, J., SOBCZYK, W. Odpady z tworzyw sztucznych i ich recykling. Edukacja-Technika-Informatyka. 2014, 5(1).

[3] GRONOWICZ, J. Ochrona środowiska w transporcie lądowym. Poznań-Radom 2004.

[4] Krajowy plan rozwoju infrastruktury paliw alternatywnych.

[5] LIU, H. Science and Engineering of Droplets - Fundamentals and Applications, Noyes Publications, Park Ridge, New
Jersey, U.S., William Andrew Publishing, LLC Norwich, New York 2000.

[6] Plastics Europe, Raport 2016.

[7] PN-EN 590+A1:2011 Paliwa do pojazdów samochodowych - Oleje napędowe - Wymagania i metody badań.

Anna Skarbek-Żabkin, MEng. - Motor Transport
Institute.
e-mail: Anna.Skarbek@its.waw.pl

